THE KURUME MEDICAL JOURNAL Vol. 10, No. 3, 1963

\title{
A COMMON ANTIGEN BETWEEN CANDIDA ALBICANS AND MYCOBACTERIUM TUBERCULOSIS
}

\author{
SOJI MATSUFUJI, MASAO FUKUDA \\ AND SHIGEHISA NAKAMURA \\ Department of Medicine, Kurume University School of Medicine, \\ Kurume-shi, Japan
}

(Received for publication May 27, 1963)

Contrary to other infectius diseases, the antibody production in vivo is very low in candidiasis. Healthy individuals harbor Candida albicans saprophytically, and therefore has serologically less specificity.

As an immune reaction for Candida, agglutination test has generally been used. However, it tends to give a spontaneous agglutination ${ }^{122}$. It is slso known that a cross agglutination would occur between Candida and bacteria strains or among Candida strains themselves ${ }^{\left.23)^{4}\right)}$. $\mathrm{Akiba}^{5}$ and $\mathrm{Ata}^{6}$ ) reported that a cross reaction was observed between Candida albicans and Mycobacterium tuberculosis. A series of experiments was therefore carried out to study a common antigen for tubercle bacillus and Candida albicans.

\section{EXPERIMENT I}

Method. Immunization was carried out in the following way: Candida albicas was cultured on the Sabuoraud medium at $30^{\circ} \mathrm{C}$ for 48 hours. The grown organisms were suspended in physiolgical saline, $1 \mathrm{mg}$ per $\mathrm{ml}$, and killed by heating at $70^{\circ} \mathrm{C}$ for 30 minutes. Inceasing doses of this suspension. from 0.1 to $1.0 \mathrm{mg}$ per $\mathrm{kg}$ body weight, were injected into the ear vein of the rabbit every other day. The tubercle bacilli were grown in Sauton medium at $37^{\circ} \mathrm{C}$ for $4-8$ weeks, sterilized at $100^{\circ} \mathrm{C}$ for 60 minutes, and then suspended. The concentration of the suspension and dosage were the same as for Candida albicans. The anti-Candida immune serum and antitubercle bacillus immune serum are abbreviated herein as ACS and ATS, respectively.

A simultaneous immunization against Candida albicans and tubercle bacillus was slso attempted. These suspensions were injected into each ear vein of the rabbit every other day.

The antigen against Candida albicans was prepared as follows: Candida albicans was grown in Sabuoraud peptone medium at $30^{\circ} \mathrm{C}$ for $5-7$ weeks. The filtrate of the medium was sterilized at $70^{\circ} \mathrm{C}$ for 30 minutes, and acidified to $\mathrm{pH} 5.5$ with acetic acid. A $50 \mathrm{gm} \%$ zinc chloride solution was added gradually and under shaking until saturation, shaken for 15 minutes and then centrifuged for 10 minutes at $2000 \mathrm{rpm}$. The sediment was suspended in $1 / 10$ volume of $20 \% \mathrm{Na}_{2} \mathrm{HPO}_{4}$ solution at $37^{\circ} \mathrm{C}$ for 2 hours, then left in an ice chest overnight. A brown transparent supernatant was obtained as antigen. 
The tuberculin was made as follows: The tubercle bacilli were cultured in Sauton medium at $37^{\circ} \mathrm{C}$ for 12 weeks, sterilized at $100^{\circ} \mathrm{C}$ for 1 hour, and filtered. The filtrate was condensed to $1 / 10$ volume of its original, overlaid with toluene, and was dialyzed in running water for 48 hours, then in distilled water for 24 hours. Toluene was discarded, the filtrate was concentrated down to the original volume at about $80^{\circ} \mathrm{C}$, and adjusted to isotonicity by addition of physiological saline.

The immune blood was withdrawn from these rabbits early in the morniug while fasting. The separated serum was inactivated, mixed with the same volume of 10 $\%$ suspension of sheep erythrocytes, left at $37^{\circ} \mathrm{C}$, then at room temperature for 20 minutes each and centrifuged. To the supernatant fluid the same amount of $1 \%$ erythrocyte suspension of the sheep was added, and the mixture was treated in the same way as described to absorb normal hemagglutinin fully.

Sensitization: The sheep erythrocytes conserved in Alsever solution were washed several times with physiological saline. The sedimented erythrocytes were suspended in 60-80 volumes of the above antigen solutions, kept at $37^{\circ} \mathrm{C}$ for 2 hours while shaking every 2 minutes, and then washed several times with physiological saline, finally to be suspended in the concetration of $0.25 \%$. The tuberculin sensitized erythrocytes and Candida antigen sensitized erythrocytes are abbreviated herein as TSE and CSE, respectively.

Reaction : A series of small test tubes was filled with $0.5 \mathrm{cc}$ of physiological saline. The unknown serum was first inactivated, ridden of its hemagglutinin, and then 0.5 cc of this was added to the first test tube for two-fold serial dilution after the Widal procedure. Half $\mathrm{ml}$ of $0.25 \%$ suspension of sensitized erythrocytes was then added to each tube which was shaken and incubated for 2 hours for evaluation.

The result of the test was assessed as follows: $(+)$-when erythrocyte aggregates were formed and precipitated at the bottom. (-)-when no such aggregates were found and the erythrocytes sedimented in a ring shape.

Result: After 4 weeks of immunization, the reactions between the two immune sera and the sensitized erythrocytes were studied. The results showed that the reaction with TSE was stronger than with CSE. At the same time, a group agglutination was observed between the two antigen with both sera. The titer in ACS was 128X with CSE and 512X with tuberculin. Similarly, titers of $32 \mathrm{X}$ was obtained

TABLE 1.

Agglutination of Candida albicans sensitized erythrocytes

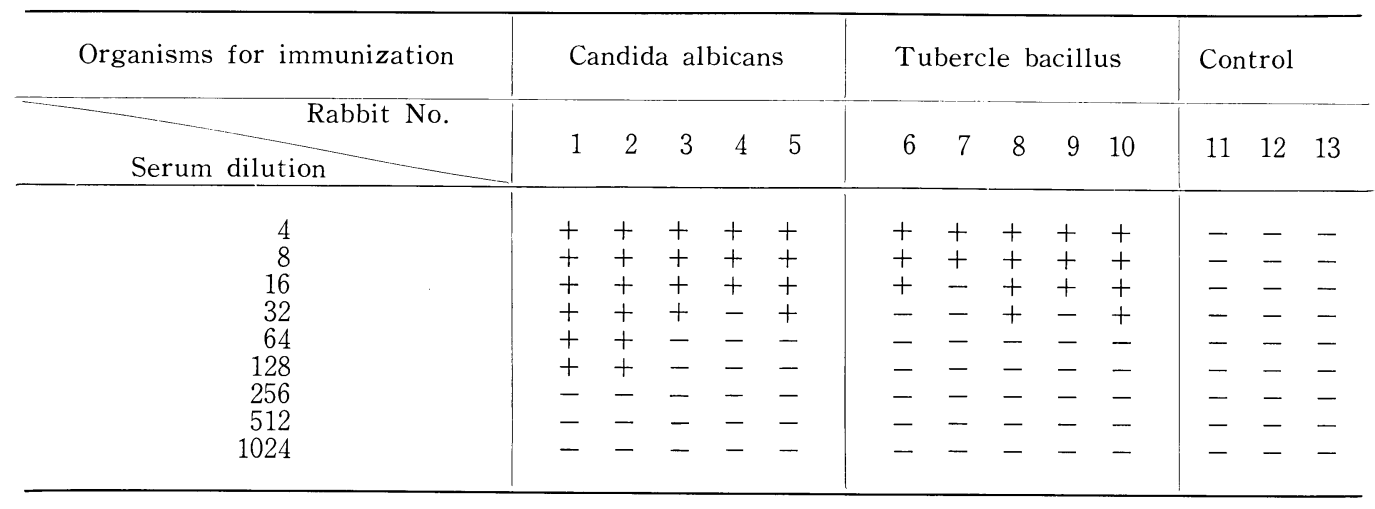


TABLE 2 .

Agglutination of Tuberculin sensitized erythrocytes

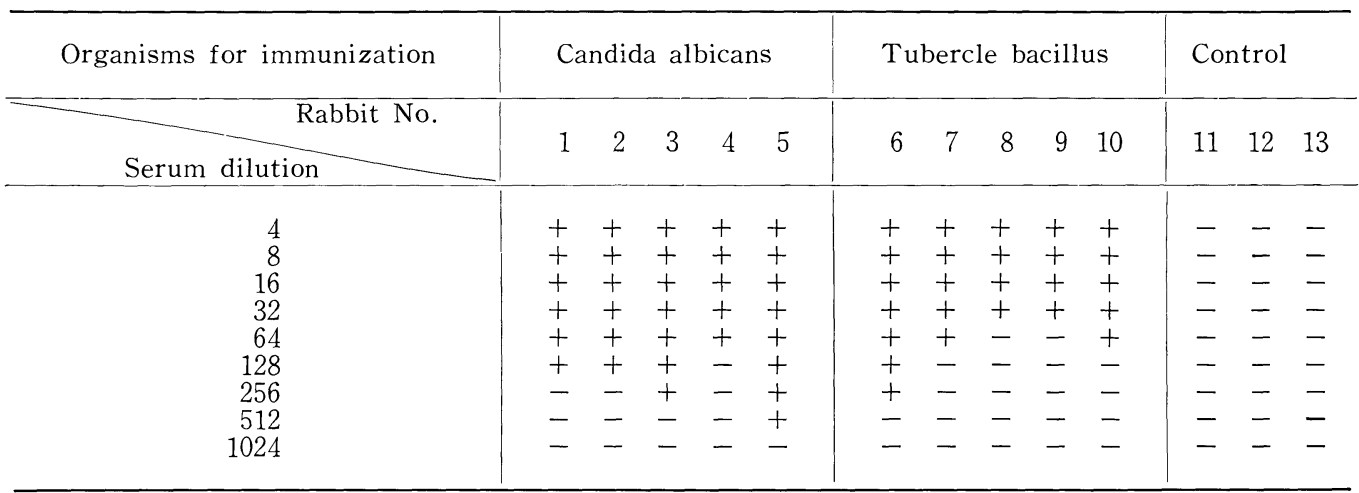

with the ATS and CSE, and 256X with the same serum and tuberculin. (Tables 1 and 2)

\section{EXPERIMENT II}

Absorption of group agglutinin was carried out in ACS with TSE and in ATS with CSE. The sera freed of the group agglutinin were subjected to the immune reaction.

1. Absorption in test tube

Method: A mixture of $2 \mathrm{cc}$ of Candida antigen solution, $10 \mathrm{cc}$ of Eagle's phosphate buffered saline and $2 \mathrm{cc}$ of washed sheep erythrocytes was incubated at $37^{\circ} \mathrm{C}$ for 3 hours while shaking at 15 minutes intervals for sensitization. The mixture was then centrifuged at $1000 \mathrm{rpm}$ for 10 minutes, the sediment was washed with Eagle's buffered saline 3 times. Two cc of thus prepared CSE was added to $1 \mathrm{cc}$ of ATS, incubated for 12 hours while shaking every 2-3 hours, and centrifuged. The supernatant represented ATS absorbed by CSE. The same procedure was repeated with $0.8 \mathrm{cc}$ of original tuberculin solution, $10 \mathrm{cc}$ of Eagle's saline and $2 \mathrm{cc}$ of washed erythrocytes to obtaine TSE, and exactly the same procedure was used to prepare ACS absorbed

TABLE 3.

Aggluiination in ACS after absorption with TSE

\begin{tabular}{|c|c|c|c|c|}
\hline Agglutination & \multicolumn{2}{|c|}{ Agglutin titer for TSE } & \multicolumn{2}{|c|}{ Agglutin titer for CSE } \\
\hline Absorption & Before absorption & After absorption & Before absorption & After absorption \\
\hline Serum dilution & $+\infty$ ำ & 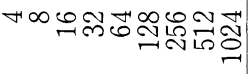 & 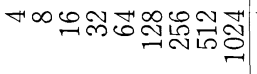 & 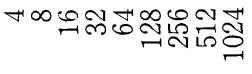 \\
\hline $\begin{array}{r}\text { Rabbit No. } 29 \\
30 \\
31 \\
32 \\
33\end{array}$ & $\begin{array}{l}+++++---- \\
+++++++-- \\
++++++--- \\
+++++---- \\
++++++---\end{array}$ & $\begin{array}{l}--------- \\
--------- \\
--------- \\
--------- \\
---------\end{array}$ & $\begin{array}{l}++++++--- \\
++++++--- \\
++++++--- \\
+++++---- \\
++++++---\end{array}$ & $\begin{array}{l}++------- \\
+++------ \\
++------- \\
+-------- \\
+++------\end{array}$ \\
\hline
\end{tabular}


by TSE. Immune reactions were carried out with these sera with the following results.

Results: Table 3 shows that the agglutin for TSE in ACS was completely absorbed by TSE and the titer for CSE was markedly reduced. Similar complete absorption of agglutinin for CSE was observed with ATS, but the reduction of titer for TSE was slight in this case. (Table 4)

TABLE 4 .

Agglutination in ATS after absorption with CSE

\begin{tabular}{|c|c|c|c|c|}
\hline Aggiutination & \multicolumn{2}{|c|}{ Agglutin titer for CSE } & \multicolumn{2}{|c|}{ Agglutin titer for TSE } \\
\hline Absorption & Before absorption & After absorption & Before absorption & After absorption \\
\hline Serum dilution & 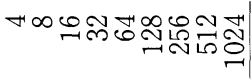 & | & 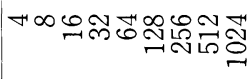 & 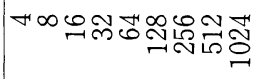 \\
\hline $\begin{array}{r}\text { Rabbit No. } 34 \\
35 \\
36 \\
37 \\
38\end{array}$ & $\begin{array}{l}++++----- \\
+++++---- \\
+++++=--- \\
++++----- \\
++++-----\end{array}$ & $\begin{array}{l}--------- \\
--------- \\
--------- \\
--------- \\
---------\end{array}$ & $\begin{array}{l}+++++++-- \\
++++++++- \\
+++++++- \\
+++++++- \\
++++++---\end{array}$ & $\begin{array}{l}++++++--- \\
+++++++=- \\
++++++-= \\
+++++++-- \\
+++++----\end{array}$ \\
\hline
\end{tabular}

\section{Absorption in vivo}

Method: Rabbits immunized against Candida were injected subcutaneously daily with killed tubercle bacilli in the dose of $1 \mathrm{mg} / \mathrm{kg}$ for 36 days. The serum was subjected to the study. Rabbits immunized against tubercle bacilli were treated in the same manner with $10 \mathrm{mg}$ of killed Candida per $/ \mathrm{kg}$.

Results: When rabbit immunized against Candida were treated with large doses of killed tubercle bacilli, the agglutin titer for CSE was warkedly reduced. (Table 5)

TABLE 5 .

Agglutination of CSE with serum obtained from rabbit immunized against Candida albicans and given excessive doses of killed tubercle bacilli

\begin{tabular}{|c|c|c|c|c|c|c|c|c|c|c|c|c|c|}
\hline \multirow{3}{*}{$\begin{array}{l}\text { Agglutination } \\
\text { Days }\end{array}$} & \multicolumn{13}{|c|}{ Agglutinin titer for CSE } \\
\hline & \multirow{2}{*}{$\begin{array}{c}\text { Before } \\
\text { absorption }\end{array}$} & \multicolumn{9}{|c|}{ After absorption } & \multirow[b]{2}{*}{30} & \multirow[b]{2}{*}{33} & \multirow[b]{2}{*}{36} \\
\hline & & 3 & 6 & 9 & 12 & 15 & 18 & 21 & 24 & 27 & & & \\
\hline $\begin{array}{ll}\text { Rabbit No. } & 39 \\
& 40 \\
& 41 \\
& 42 \\
& 43\end{array}$ & $\begin{array}{r}128 \\
64 \\
64 \\
32 \\
32\end{array}$ & $\begin{array}{r}128 \\
64 \\
32 \\
32 \\
16\end{array}$ & $\begin{array}{r}64 \\
32 \\
32 \\
16 \\
8\end{array}$ & $\begin{array}{r}64 \\
32 \\
16 \\
8 \\
8\end{array}$ & $\begin{array}{r}32 \\
16 \\
8 \\
4 \\
16\end{array}$ & $\begin{array}{r}16 \\
16 \\
4 \\
16 \\
16\end{array}$ & $\begin{array}{r}32 \\
32 \\
4 \\
32 \\
32\end{array}$ & $\begin{array}{r}16 \\
16 \\
8 \\
16 \\
32\end{array}$ & $\begin{array}{r}32 \\
8 \\
32 \\
16 \\
16\end{array}$ & $\begin{array}{r}32 \\
4 \\
64 \\
8 \\
8\end{array}$ & $\begin{array}{r}8 \\
4 \\
16 \\
8 \\
16\end{array}$ & $\begin{array}{r}8 \\
8 \\
16 \\
16 \\
8\end{array}$ & $\begin{array}{l}16 \\
32 \\
32 \\
16 \\
16\end{array}$ \\
\hline
\end{tabular}

The reverse of this showed a slight decline of the titer which increased later. (Table 6) 
TABLE 6.

Agglutination of TSE with serum obtained from rabbit immunized against tubercle bacilli and given excessive doses of killed Candida albicans

\begin{tabular}{|c|c|c|c|c|c|c|c|c|c|c|c|c|c|}
\hline \multirow{3}{*}{$\frac{\text { Agglutination }}{\text { Days }}$} & \multicolumn{13}{|c|}{ Agglutinin titer for TSE } \\
\hline & \multirow{2}{*}{$\begin{array}{c}\text { Before } \\
\text { absorption }\end{array}$} & \multicolumn{9}{|c|}{ After absorption } & \multirow[b]{2}{*}{30} & \multirow[b]{2}{*}{33} & \multirow[b]{2}{*}{36} \\
\hline & & 3 & 6 & 9 & 12 & 15 & 18 & 21 & 24 & 27 & & & \\
\hline $\begin{array}{ll}\text { Rabbit No. } 44 \\
\\
45 \\
46 \\
47 \\
48\end{array}$ & $\begin{array}{l}256 \\
256 \\
256 \\
128 \\
128\end{array}$ & $\begin{array}{l}256 \\
256 \\
128 \\
128 \\
128\end{array}$ & $\begin{array}{r}256 \\
128 \\
64 \\
64 \\
128\end{array}$ & $\begin{array}{l}128 \\
128 \\
128 \\
128 \\
256\end{array}$ & $\begin{array}{l}128 \\
256 \\
256 \\
128 \\
128\end{array}$ & $\begin{array}{l}128 \\
256 \\
128 \\
256 \\
128\end{array}$ & $\begin{array}{r}256 \\
256 \\
128 \\
128 \\
64\end{array}$ & $\begin{array}{l}128 \\
256 \\
256 \\
256 \\
128\end{array}$ & $\begin{array}{l}128 \\
256 \\
256 \\
256 \\
256\end{array}$ & $\begin{array}{l}256 \\
256 \\
128 \\
256 \\
256\end{array}$ & $\begin{array}{l}128 \\
128 \\
128 \\
128 \\
128\end{array}$ & $\begin{array}{l}128 \\
256 \\
256 \\
128 \\
128\end{array}$ & $\begin{array}{r}128 \\
256 \\
256 \\
128 \\
64\end{array}$ \\
\hline
\end{tabular}

\section{EXPERIMENT III}

Method

1. Antigen analysis for Candida

Dried Candida organisms were ground, added with 10 volumes of $0.1 \mathrm{~N} \mathrm{NaOH}$ and stirred for 3 days. After centrifugation, the supernatant was dialyzed, filtered, condensed, the $\mathrm{pH}$ adjusted to 4.0 with $0.25 \mathrm{~N}$ trichloroacetic acid (TCA) and an equal volume of ethanol was added. The precipitate was washed with acetone several times and dried. The dried material was washed with TCA several times until amber supernatant became clear. The precipitate was then dialyzed overnight to remove TCA, reprecipited with ethanol and dried after acetone washing. The material thus prepared gave negative protein reaction when studied by Biuret, ninhydrin, Millon, xanthprotein reactions and TCA precipitation. Reactions to Fehling, Benedict and Molish reagents were equivocal.

Phenol treatment was carried out as follow: Dried Candida organisms were extracted with 90-95\% phenol for 3 days under agitation, filtered and the precitate was thoroughly washed with ethanol to remove phenol. The precipitate was heated in distilled water at $100^{\circ} \mathrm{C}$ for one hour, dialyzed against running water for 2 days, filtered and condensed. Three volumes of absolute ethanol were added to it, sodium acetate was then added to the concentration of $1 \%$, left overnight, the precipitate was washed with acetone several times. The powder thus prepared was dissolved in distilled water, dialyzed against distilled water, condensed, and precipitated with 3 volumes of ethanol, the precipitae was washed with acetone several times and dried. The entire procedure was repeated 3 times.

The final material was positive to Molish and carbazole reactions, negative to Fehling test, and negative to Benedict, ninhydrin, Millon and xanthoprotein tests, no turbdity with TCA and gave a positive Sakaguchi reaction.

2. Chemical analysis of tuberculin

To the original tuberculin solution was added $50 \%$ TCA to the final concentration of $10 \%$ TCA. The mixture was left overnight at room temperature, centrifuged. The precipitate was dissolved $i n 0.1 \mathrm{~N} \mathrm{NaOH}$ and the TCA precipitation was repeated several times. The final precıpitate was dialyzed against distilled water overnight, reprecipitated with ethanol, washed with acetone several times and dried. The 
chemical properties of the final product revealed positive protein reactions, negative sugar reactions and equivocal Molish test.

Similar chemical characterization was carried out on the $10 \%$ TCA soluble fraction. The TCA supernatant was precipitated with 5 volumes of methanol after being left overnight. The precipitate was dissolved in a small volume of distilled water, precipitated with TCA, the supernatant was treated with methanol and the same proceduce was repeated. The final precipitate was dialyzed against distilled water overnight, concentrated, reprecipitated with ethanol, and washed with acetone and dried.

The reactions this product gave were positive for sugar and negative for protein.

3. Sensitization of erythrocytes with purified antigen fractions and aggultination reaction.

The protein and polysaccharide fractions were used in $1 \%$ solution to sensitize erythrocytes and agglutinaion was carried out in the method described.

Results: With the purified fraction of Candida, the agglutination reaction was still demonstrable although the titers were lower, and the protein fraction gave a weaker reaction than the polysaccharide fraction.

In ATS, the same but definite reaction was seen with Candida polysaccharide, no

TABLE 7.

Agglutination of erythrocytes sensitized with various fractions of Candida albicans

\begin{tabular}{|c|c|c|c|c|c|c|c|c|c|c|c|c|}
\hline Organisms for immunization & \multicolumn{5}{|c|}{ Candida albicans } & \multicolumn{5}{|c|}{ Tubercle bacillus } & \multicolumn{2}{|c|}{ Control } \\
\hline Rabbit No. & 49 & 50 & 51 & 52 & 53 & 54 & 55 & 56 & 57 & 58 & 59 & 60 \\
\hline Candida albicans & 128 & 128 & 256 & 128 & 64 & 32 & 64 & 64 & 32 & 16 & 0 & 0 \\
\hline $\begin{array}{l}\text { Protein fraction of Candida } \\
\text { albicans }\end{array}$ & 16 & 8 & 16 & 8 & 8 & 0 & 8 & 4 & 0 & 0 & 0 & 0 \\
\hline $\begin{array}{l}\text { Polysaccharida fraction of } \\
\text { Candida albicans }\end{array}$ & 64 & 64 & 128 & 128 & 32 & 16 & 16 & 16 & 8 & 16 & 0 & 0 \\
\hline
\end{tabular}

TABLE 8.

Agglutination of erythrocytes sensitized with various tuberculin fraction

\begin{tabular}{|c|c|c|c|c|c|c|c|c|c|c|c|c|}
\hline Organisms for immnization & \multicolumn{5}{|c|}{ Candida albicans } & \multicolumn{5}{|c|}{ Tubercle bacillus } & \multicolumn{2}{|c|}{ Control } \\
\hline Rensitized antigen & 49 & 50 & 51 & 52 & 53 & 54 & 55 & 56 & 57 & 58 & 59 & 60 \\
\hline Tuberculin & 64 & 64 & 128 & 64 & 64 & 512 & 512 & 128 & 256 & 64 & 0 & 0 \\
\hline Protein fraction of tuberculin & 0 & 0 & 8 & 0 & 0 & 4 & 4 & 0 & 0 & 0 & 0 & 0 \\
\hline $\begin{array}{l}\text { Polysaccharide fraction of } \\
\text { tuberculin }\end{array}$ & 64 & 32 & 64 & 32 & 16 & 256 & 128 & 64 & 64 & 32 & 0 & 0 \\
\hline
\end{tabular}


demomonstrable reaction was obtained with the protein fraction. (Table 7)

Using tuberculin polysacharide fraction, the titers were somewhat lower than with crude tuberculin, but the reaction was definite. No reaction was obtained with the protein fraction to either serum. (Table 8)

Thus, polysaccharide fraction of both antigens were antigenic to both immune sera, whereas the protein fraction of Candida showed antigenicity to ACS but not to ATS. Tuberculin protein demonstrated no antigenicity to either serum.

\section{SUMMARY}

1) Antigen prepared from Candida albicans and tuberculin showed a cross reaction with anti-Candida and anti-tubercle bacillus immune sera.

2) In vitro absorption study of the common antigen demonstrated that it constitutes a greater part of the antigenicity in the Candida antigen than in tuberculin.

In vivo absorption study showed that Candida has an antigenicity similar to tubercle bacilli.

3) The polysaccharide fraction of each antigen revealed antigenic properties in both immune sera. The protein fraction of Candida antigen was antigenic in antiCandida serum, but tuberculin protein lacked in antigenicity.

4) These results suggest that the antigen shared by the both organisms is contained in the polysaccharide fraction of Candida antigen and tuberculin.

\section{REFERENCES}

1. Hoffstadt, R.E. \& Lingenfelter, J. S. : A Pulumonary infection caused by Monilia balconica. Amer. J. Trop., 9, 461, 1929.

2. Martin, D.S. : Studies on the immunologic relationships among various species of the Genus Candida. Amer. J. Trop. Med., 22, 295, 1942.

3. Sмгтн, D. T. \& Scotт, N.B. : Clinical interprelation of Middlebrook-Dubos hemagglutination test. Amer. Res. Tuberc., 62, 121, 1950.

4. Rothbard, S. D., Dooneief \& Hite, K. E. : Practical application of hemagglutlnation reaction in tuberculosis. Proc. Soc. Exp. Biol. \& Med., 74, 72, 1950.

5. Akiba, T., Iwata, K. \& Inoue, S. : Studies on the serologic diagnosis of candidiasis. SOGO-IGAKU., 12, 605, 1953.

6. AтA, S. : Shudies on the etiologic mechanisms of candidiasis. SOGO-IGAKU., 12, 691, 1955. 